\title{
Finansowanie Kampanii Wyborczych Do Legislatur Stanowych W Systemie Federalnym Stanów Zjednoczonych [Financing of Electoral Campaigns to State Legislatures in the Federal System of USA]
}

Wydawnictwo Adam Marszałek, Toruń 2010 (pp. 344)

In 2010, a book written by Bogdan Mucha entitled 'Financing electoral campaigns to state legislatures in the US federal system' was published. As far as I know, it has not been revived in the well-known legal or political science magazine, that is why it is placement in 'Białostockie Studia Prawnicze' [Białystok Legal Sudies], which are fully devoted to issues of elections and voting rights, is justifiable. The reviewed book is a really important position which supplements the important gap in the field of studies devoted to the political system of United States (especially within the last years, valuable Polish language monograph studies are very rare), as well as to the issues of voting right.

The selection of topic shall be accepted with appreciation for at least two reasons. Firstly, the, problematic issue of campaign financing (election campaign) is a controversial issue not only in USA but also in other democratic countries. Appearing disputes result mainly from the fact that complication of election procedures requires a large amount (not to say: higher and higher) financial assets. Neither political parties nor candidates are not able to cover necessary costs out of their pockets. The result of public debates on the source of electoral procedures financing are different models of adopted solutions. B. Mucha Limits himself in the performed analysis to the US territory and here - what can be found out by the reader of the reviewed book - you may encounter differentiated approach to this issue. Secondly, the study concerns - in accordance with the title - electoral campaigns to 
state parliaments. The author undertook an analysis of state law which must arouse recognition due to the necessity to get acquaint with solutions that functions in all EU Member Stares. It is worth-underlining also in this context that the problems of American federalism is quite rarely adopted by Polish authors in monograph studies (recently in works of Tomasz Wieciech, nevertheless, the top place is taken by the book of Jerzy Jaskiernia of 1979 entitled Pozycja stanó $w$ w systemie federalnym USA) [Position of United States in the USA federal system].

B. Mucha monography consists of four chapters preceded by a brief Introduction. The sum up of the considerations was provided by the author on the several pages of Conclusion. The book was also provided with an extensive References divided into components: non-serial publications, studies and articles, other publications and press articles, jurisdiction of federal and state courts, legal acts and documents other than websites. I wish to bring your attention to the references because it gives the notion of solidarity of author's scientific workshop. Regardless off its volume (44 pages) it also includes a list of numerous sources and studies in English language and - as I believe - all the most important monographs of Polish authors which should be used in preparation of the topic. However, there is a lack of broader use of studies and articles in the Polish language.

Book publication via well-known publishing house, recognizable and valued within the circle of political scientists and constitutionalists, ensures a solid technical preparation of the book. Nevertheless, I had an opportunity to see some inadequacy in several places (for e.g. on the page 334, there is provided a use of Polish translation of USA Constitution without provision of translator name or even the place and date of translation issue). They are so tiny, however, that they cannot decrease the general value of work in any degree.

Particular chapters are devoted to: general characteristics of elections to state legislatures and state legal regulations of election campaigns, normative constructions of election funds, methods of financing of elections to the court legislatures as well as the significance of state elections financing methods to receive the aim in the form of 'pure elections'. Even if at first glance, the reader may get the impression of some confusion of plots of the conducted considerations, reading of the book protects the idea of author regarding its composition. It is also worth mentioning that the chapters are proportionally extensive, at least in terms of their volume. However, the internal structure can raise some doubts which will be mentioned below.

The aim of the paper, indicated in the Introduction, shall be evaluated as extremely ambitious. It was determined as 'a demonstration of election campaigns functioning mechanisms to the state legislation authorities within the background of dynamically evolving federal system'. Such a generally outlined aim is specified by the author pointing out that 'it is to show the interaction between system elements and effects of adopted solutions in the reflection of liberal model of campaign financing and model which reflects public financing to reach an effect in a form of 'pure 
Financing of Electoral Campaigns to State Legislatures in the Federal System of USA

elections' in the broad scope (page 7). The two basic financing models for election campaigns indicated in this way have been subject to deepened analysis in further part of this book, especially in Chapters III and IV. Preceding further remarks, it should be mentioned here that a detail analysis of election campaign financing to all state legislatures would be impossible. That is why the author is rightly limited to indication of model solutions.

In this case, those are regulations adopted in Illinois (a liberal model) as well as Maine and Arizona (a model of full financing from public funds).

Chapter I has the following wording: General characteristics of elections to the court legislatures and legal regulations of state electoral campaigns. First of all, the author went on to analyse the position of states in the federal political system of United States. Next, he characterised the competences to regulate state election processes in American federal system jointly with the problematic issue of so-called supremacy clause. Apart from the fact that the content of pointed out issues was not expreses expressis verbis in the title of he chapter, it results logically from the whole project and its title as well as from the aim of paper characterised above. It is hard to imagine any construction of introductory issues if the subject of analysis is constituted by norms of state law.

In this part, the subject of author's interests is the general political system position of states within the background of the federalism theory, resolutions of USA constitution of 1787 and court ruling. This extremely interesting issue cannot overshadow the basic topic of the monograph, nevertheless, the author gives a show of its scientific capabilities, extremal reliability and erudition. First pages of the book are read with a real pleasure, especially that the author does not neglect the reference to the source materials thanks to which the reader receives a hint to take up its own research. The demonstration of high independence in the sphere of lawmaking allows to better understand the significance of state legislation for regulating electoral processes including the financing of election campaigns, especially in the background of historical and cultural differences between individual states. In this Place, B. Mucha underlines the significance of Voting Rights Act of 1965 (p. 28-29) which prevented the adoption of discriminatory laws against minorities (formerly the Afro-American people, now the ban is more universal) and guaranteed equality of voting right also at state level. In this manner, through the actions of the federal legislator and the adjudication activity of courts, the universalization of active (largely passive) electoral law in the entire Union took place.

Two last points of chapter I were devoted to purely electoral issues. First of all, decisions of federal law were discussed, and then, state regulations. It should be emphasized that both of the commented points have an almost identical internal layout, thanks to which the reader receives a precise picture of the legal regulation of electoral law at the federal and state level. In this part, the author points out the process of voting rights in the over 200 years history of the Union (p. 43-44), the 
scope of federal authorities' entitlements within the scope of voting rights (p. 44-55 as well as significance of federal courts jurisdiction (p. 55 and n.), also within the scope of election campaign financing (p. 59-74). Proceeding to the state regulations B. Mucha discusses preliminarily the issues of voting right is state constitutions (pages 74-81). Due to the extensiveness and particularity of regulations, they have (apart from norms of federal law) decisive significant for the legislator decisions within the subject of introduction of particular solutions also within the scope of election campaigns financing. One may have here some reservations to the analysis of the phenomenon gerrymande- ring nevertheless, the explanation for this matter of facts shall be deemed logical from the point of view of primary topic of the paper (s. 81). Considerations regarding the significance of state jurisdiction for regulation of election procedures (pages 81-83) are very humble, and within the subject of election campaign financing, the author limited himself to just one paragraph. Probably, the author reached an assumption that the reader would have an opportunity to get acquaint to the more detailed regulations in next parts of the book, nevertheless the said analysis should be treated as too general. In the section devoted to the meaning of the judgments of state courts, the author gives a testimony to the knowledge of the latest trends in the jurisdiction, seeing the growing role of state courts in the area of voting rights, including the financing of election campaigns (pp. 81-87).

Chapter II title is: Normative construction of electoral funds. B. Mucha discussed thee a notion and functions of electoral funds, their systematics, basic forms of state electoral funds including aims of their destination. It is pity that the author did not precede the considerations on the election funds with more general considerations in which he would present the importance of this institution for the specified purpose of work. The need to analyse the election funds in the paper on financing of election campaigns is quite obvious, nevertheless, from the point of view of reliability of scientific bases, it would be useful to include a mention on this topic (especially due to the fact that it is also not perceptible in the Introduction). Specifying the legal norms governing the election funds, B. Mucha indicates that, in many cases, the solutions adopted by particular states have become a source of inspiration for the federal legislator ( $p$. 90-91). The author determines and characterises the functions of electoral funds in an interesting manner. Four of them are distinguished: protective, regulatory, simulative and reporting-control (pp. 91-99). Subsequently, B. Mucha discusses the systematics (or rather: classification) of electoral funds (pp. 99-103). The authors shall be praised again for the clarity and reliability of reasoning. Lack of reference to relevant subject literature (especially that B. Mucha does not spare bibliographic indications in other fragments) shows that this fragment includes original conclusions of the author.

First two points of chapter II have introductory meaning. Definitely, the most comprehensive part of this chapter are considerations on basic forms of state election funds (for this reason, it is possible to notice a certain defect in the internal structure 
of the commented chapter). The election funds of candidates are divided into supplied with internal sources, i.e. candidate's own funds, and supplied with external sources: payments of individual persons, fees from election funds of political parties as well as funds and payments of legal persons beyond a party. Such an internal structure of the commented part of this book may bring some doubts, especially in the presence of the abovementioned division of funds in accordance with the subject criterion. Certainly, the author wanted to highlight the basic meaning of election funds of candidates in this manner (cf. comments on p. 103), nevertheless, this made the text structure unclear.

Regardless of the presented structural doubts, the commented part of the book must arouse attention of even poorly interested reader. Characterising the financing of electoral campaigns by the candidate out of its pocket B. Mucha relates to the practice including specific financial expenses in particular elections (pp. 105-113). This gives a certain picture of the chance dependence for an electoral success of the candidate - colloquially speaking - the wealth of his portfolio. What is particularly interesting (especially for political scientists) are comments referring to political debutants who, for the first time, attempted to obtain a representative's mandate and, on the other hand, persons applying for re-election. The author also brings attention to the federal provisions which aim is to equalize chances of candidates.

Subsequently, B. Mucha deals with the issue of external sources of supplying candidates' electoral funds. For natural reasons, this issue remains in the area of public interest due to the threat of political corruption (p. 113). Hence, certain restrictions in US law arise when it comes to the scope of financing of election campaigns. Payments from private persons are the sign of their support to the candidate and views expressed by him. They can adopt extremely diverse forms, including cash payments and even personal or material benefits (p. 117). In majority of states, there are limits that determine the maximum amount of payments including the prohibition of financing by specific categories of people (pp. 118-122). The external source shall be considered as payments from electoral funds of political parties. Approaching this train of thought, B. Mucha justly notices that the basic task of two dominant parties in the American political scene (Republicans and Democrats) is supporting their own candidates in federal and state elections (p. 122). Therefore, he analyses the national (federal) funds of both parties, and only then - state funds. B. Mucha pays a lot of attention to funds and contributions from non-party legal entities: corporations and trade unions and other organizations (p. 128 and n.).

At the end of considerations provided for electoral funds, B. Mucha analyses aims of spending of accumulated financial assets. He divides them into four groups, but the large amount of funds is spent on advertisement in mass media (p. 163). He analyses (unfortunately in a quite superficial manner) the stand of the Supreme Court which questioned, as compliant with the Constitution, the limitation of expenses on advertisement, seeing it as restriction of freedom of speech (pp. 165-166). 
Chapter III was entitled: Financing methods of elections to the court legislatures. It consists of five points (differentiated in volume) on: general conditions for financing the election to state parliaments, bases of the liberal model of financing the election financed from public funds, and federal implementations of financing the election from public funds. First of all, B. Mucha characterise the general scope of complicated factors which are determined by election financing methods. Determinants of political nature are believed as the most important (pp. 169-173). Factors connected with the structure of election districts is provided on second place (pp. 173-175). There is no doubt that the size of the borough and, especially, the number of potential electros, significantly determines the amount of expenses incurred for conducting election campaign. Next, B. Mucha draws the attention to problems connected with collection of appropriate funds by a political candidate who competes for re-election (pp. 175-177).

he greatest deal of space is spend by B. Mucha on legal determinants of elections financing. He indicates that they include, in particular, the determination of payment amounts, limitations in the expenditure of accumulated funds and financing of political campaigns from public assets (p. 177 and n.). The author draws the attention to differentiation of state regulations in the subject of potential possibility of spending funds, highlighting that the collected funds can be also spent on other purposes than candidate promotion, especially referendum campaign (pp. 182-183). An important rule governing the process of spending money on election campaigns is the openness and related necessity to submit reports (pp. 184-191). Due to this, the voters receive the full image of involved entities and support of a specified candidate. Thus, the principle of transparency enables the public, in a later period, to control the manner of adopting decisions by the representatives.

In chapter III, B.Mucha placed arrangements in a form of two basic models of election campaign financing: liberal financing and financing from public funds. Liberal model is characterised by lack of practical limitations when it comes to the source and the amount of performed payments (p. 191). The only guarantee against possible fraud is the disclosure of financing sources, manifested in the necessity to submit reports. When it comes to specific solutions adopted in particular states which adopt liberal model, they are quite different.

Much more uncertainty is connected with the alternative model, which allows for public financing of election campaigns. In relation to this issue, B. Mucha analyses the differences between European countries and USA (pp. 199-209). Due to controversies within the background of elections financing (and especially of political parties), full financing of political campaigns is present in just six states. In the following 12, a partial financing of election campaigns from public funds was adopted (p. 211).

The last, IV Chapter of the books is entitled: The significance of financing methods of state election campaigns for establishment of the aim within the form of "pure 
Financing of Electoral Campaigns to State Legislatures in the Federal System of USA

elections'. The concept of 'pure election', and in particular, its reference to the concept of 'fair' elections, is of key importance for B. Mucha's considerations. Unfortunately, there are no definitions of this concept at the start of the commented chapter, as a result of which, a reader has to independently draw the conclusion that it concerns the elimination of abuse in the field of financing election campaign (cf. comment on p. 228). Chapter IV consists of three points. The first of them is focused on the liberal model functioning in the state of Illinois, the second and the third one on the model of financing from public funds applied in the state of Maine and Arizona, respectively. In the third point, the author draws conclusions from the comparison of both models in the context of achieving the aim in the form of 'pure elections'.

In Illinois, in accordance with the assumptions of the liberal model, legal regulation of election campaign financing is limited to the necessity of submitting a report. There are, however, no restrictions on the subject of payments made, as well as spending of accumulated funds (p. 232). In Maine, in turn, since 1996, the law that implements the model of financing the election campaign from public funds has been in force (p. 245). The State of Maine adopted precedential solutions, imitated later in several other states. The essence of the adopted solution in Maine is the prohibition of collecting payments from private persons by candidates who use public funds ( $\mathrm{p}$. 246). The candidate has a possibility of selection of its campaign financing. Similar model of electoral campaign financing is present in 1998 in the state of Arizona. In this case, the candidate can also declare financing of the campaign from his own funds, then, his opponent - provided he adopted financing from public funds receives a compensatory surcharge - (p. 263).

Evaluating the characterised models in the context of 'clean elections', B. Mucha concludes that the establishment of transparent mechanisms for financing election campaigns supports competitiveness of election procedure and involvement in it of voters themselves (p. 280). A particular significance for respecting the idea of 'pure choice' is the obligation to submit a report - in both models) (p. 282). Nevertheless, the solutions used in the public funding model are the most useful (pp. 282-283).

In conclusion, B. Mucha performs the summing up of his considerations. He notices the complication of the legal situation of a candidate appearing in elections to the state legislature who is bound by norms of federal and state law (p. 285). He draws attention to the legal and institutional weakness of political parties, because funds are collected by individual candidates, not by parties (p. 286).

He emphasizes that the issue of financing election campaigns is of public interest, not just politicians (pp. 287-288). B. Mucha draws the attention to the advantages of financing an election campaign from public funds, indicating that the liberal model in modern times shows larger and larger weaknesses, which is proved by new corruption scandals (pp. 288-289). At the same time, it is found, that radical solution is unacceptable which completely eliminates the incomes from private persons (p. 290). 
It is necessary to share the view presented in the reviewed book that candidates in the United States conduct two campaigns: one for voters' support and the other one for funds which allow for conducting the actual campaign (p. 240). Fortunately, there is no simple relationship between the amount of funds raised and the actual support of the electorate. With this, appropriate money certainly facilitates the performance of effective election campaign, but it cannot replace the political program offered to the voters and personal features of candidates.

Undoubtedly, the book of B. Mucha needs attention and recognition both in terms of topic selection and its preparation. For those interested in the functioning of the US political system and the issue of election and electoral law, it should be a compulsory reading. 